\title{
Toxicological Evaluation of Bisphenol A and Its Analogues
}

\author{
Bisfenol A ve Analoglarının Toksikolojik Değerlendirilmesi
}

\author{
(1) İrem IYiGÜNDOĞDU1, (1) Aylin ÜSTÜNDAĞ2*, (1) Yalçın DUYDU2 \\ 1 Gazi University Faculty of Pharmacy, Department of Toxicology, Ankara, Turkey \\ 2Ankara University Faculty of Pharmacy, Department of Toxicology, Ankara, Turkey
}

\begin{abstract}
Bisphenol A (BPA) is known as one of the oldest synthetic compounds with endocrine disrupting activity. It is commonly used in the production of epoxy resins, polycarbonates, dental fillings, food storage containers, baby bottles, and water containers. BPA is associated with various health problems such as obesity, diabetes, chronic respiratory diseases, cardiovascular diseases, renal diseases, behavior disorders, breast cancer, tooth development disorders, and reproductive disorders. Increasing health concerns have led the industry to seek alternatives to BPA. As BPA is now being excluded from several consumer products, the use of alternative compounds is increasing. However, the chemicals used to replace BPA are also BP analogues and may have similar or higher toxicological effects on organisms. The aim of this review is to focus on the toxicological profiles of different BP analogues (i.e. BPS and BPF) which are increasingly used today as alternative to BPA.
\end{abstract}

Key words: Bisphenols, bisphenol A, endocrine disruptor, bisphenol S, bisphenol F

öz

Bisfenol A (BPA) endokrin aktiviteye sahip bilinen en eski bileşiklerden biridir. BPA epoksi reçineler, polikarbonatlar, diş dolguları, yemek saklama kapları, bebek biberonları ve su bidonlarının üretiminde yaygın olarak kullanılmaktadır. BPA obezite, diyabet, kronik solunum hastalıkları, kardiyovasküler hastalıklar, renal hastalıklar, davranış bozuklukları, meme kanseri, diş gelişimi bozuklukları ve üreme bozuklukları gibi çeşitli sağlık sorunlarıyla iliş̧kilendirilmiştir. Artan sağlık endişeleri endüstriyi BPA alternatifleri aramaya yönlendirmiştir. Günümüzde BPA tüketici ürünlerinden çıkarılmaya bașlandığı için, alternatif bileșiklerin kullanımı artmaktadır. Ancak, BPA yerine kullanılan kimyasallar da BP analoglarıdır ve organizmalar üzerinde benzer toksikolojik etkileri olabilir. Bu derlemenin amacı günümüzde BPA'ya artan miktarlarda alternatif olarak kullanılan BP analoglarının (BPS ve BPF) toksikolojik profillerine odaklanmaktadır.

Anahtar kelimeler: Bisfenoller, bisfenol A, endokrin bozucu, bisfenol S, bisfenol F

\section{INTRODUCTION}

Endocrine disruptors, such as pesticides and bisphenol A (BPA), can be defined as exogenous substances that cause different levels of changes in the evolution and function of the endocrine system!

BPs are a class of chemicals known as diphenylmethanes. BPs contain two benzene rings separated by a central carbon atom. They mostly have 4-OH substitutes on both benzene rings. Some BPs may have a sulfone group or a sulfide instead of a central carbon atom. ${ }^{2}$

Regulations and increasing concerns among the public have led the industry to seek alternatives for BPA, and as BPA has begun to be excluded from products due to consumer concern the use of alternative BPs has increased and BPA has begun to be replaced by its chemical analogues. ${ }^{3-6}$
The chemicals used to replace BPA also have BP structures and may have similar effects on organisms. ${ }^{5}$ According to research, BPA analogues may result in toxic effects similar to or greater than those of BPA. ${ }^{4}$

\section{Bisphenol}

The chemical nomenclature of BPA is 2,2-bis (4-hydroxyphenyl) propane and it has a molecular weight of $228.29 \mathrm{~g} / \mathrm{mol}$. 4,8 If its physical properties are examined it is seen that it has water solubility of approximately 120-130 ppm, low volatility, low air emission, and a short photooxidation half-life $(<7 \mathrm{~h}) .^{1.8}$

BPA is known as one of the oldest synthetic compounds with endocrine activity and was first discovered by Dianin in $1891 .{ }^{19} \mathrm{It}$ is one of the chemicals produced in the largest quantities in the world, with an estimated 5-6.8 million tons produced per year, and it is used in a wide range of areas. ${ }^{1.410}$ While $70 \%$ of the BPA 
produced is used in the production of polycarbonate plastics, $25 \%$ is used in the production of epoxy resins. ${ }^{10}$

BPA is commonly used in the production of epoxy resins, polycarbonates, baby bottles, food storage containers, dental fillings, and water containers. ${ }^{2,8}$ BPA is also seen in thermographic and pressure-sensitive paper, bank notes, receipts, and toys. ${ }^{3,6,8}$ In addition, it is used in medical devices and health care services such as eye lenses, newborn incubators, and nebulizers.'

BPA exposure mainly occurs through food. ${ }^{4}$ BPA contamination in foods usually happens as a result of migration from containers including it...$^{10}$ Exposure is caused by consuming food and beverages in recycled bottles, cans covered with epoxy resins, and polycarbonate containers that BPA has leaked into.' Environmental factors such as temperature, heat, and acidity increase the hydrolysis of ester bonds that bond BPA molecules to epoxy resins and polycarbonates. BPA leakage in polycarbonates happens more often to solutions with low $\mathrm{pH}$ values, whereas in epoxy resins higher temperature increases BPA leakage.' When exposure concentrations are examined it is seen that in solid canned food mean concentrations of exposure vary from $10 \mu \mathrm{g} \mathrm{kg}^{-1}$ to $70 \mu \mathrm{g} \mathrm{kg}^{-1}$, whereas in liquid canned food they range from $1 \mu \mathrm{g} \mathrm{L}^{-1}$ to $23 \mu \mathrm{g} \mathrm{L^{-1 }}$. $^{2}$ Fish, dairy products, meat, canned vegetables, and baby food are examples of goods that may contain BPA. ${ }^{10}$ The specific migration limit of BPA is determined as $0.6 \mathrm{mg} / \mathrm{kg}$ in the 2002/72/EC Commission Directive and in the Turkish Food Codex. ${ }^{10}$

In addition to the sources of exposure mentioned above, dust may also cause significant exposure by inhalation of indoor dust and thermal paper may cause transdermal exposure from the skin. ${ }^{49,11,1,2}$ Dental composite resins may also cause BPA to leak into saliva.' Other than these, sources such as water sources in nature, tap water, air, and medical devices are examples of sources of exposure.1.11 BPA used in epoxy-based floor materials, adhesives, paints, and electronic devices is another source of exposure.' BPA is detected in blood, urine, and sweat in humans."

Generally it is suggested that BPA is bioactivated by oxidation reactions catalyzed by cytochrome P450 and detoxified by glucuronidation reactions and sulfation reactions. It is shown that the toxic effects of BPA decrease in the presence of ADH, ALDH2, and SULT1E1 and increase in the presence of CYP2E1. ${ }^{13}$

The main mechanism of the toxic effects induced by BPA is endocrine disruption. This property may cause both developmental and reproductive disorders. ${ }^{2}$ BPA is associated with obesity, diabetes, breast cancer, cardiovascular diseases, renal diseases, chronic respiratory diseases, tooth development disorders, behavior disorders, and reproductive disorders. ${ }^{9.14}$

It is shown in the literature that a low dose of BPA has a negative impact on the endocrine system and may lead to primary endocrine disorders. ${ }^{1.10}$ It affects the cell signaling pathways. ${ }^{13}$ It is reported to have effects on the central nervous system, cardiovascular system, immune system, respiratory system, and renal system.1.10 It may be associated with thyroid hormone function disorders..$^{10}$ After exposure birth defects may be seen.
Pregnant women and fetuses are very sensitive to pathologies induced by BPA due to its penetration of the placenta barrier.13 In other research it was shown that BPA can pass to the fetus from the mother and can cause behavior changes and anomalies in the reproductive organs of the fetus..$^{0}$ In addition to the effects mentioned above, it is suggested that BPA has mutagenic and genotoxic potential. ${ }^{3}$

BPA can both bind to $\operatorname{Er} \alpha$ and $\operatorname{Er} \beta$ receptors and affect them by either activating or suppressing their expression. ${ }^{1.7}$ Its relative binding affinity is predicted to be 1000-10,000 times lower than that of estradiol and it is classified as a weak environmental estrogen.?

BPA can act as a potential antagonist of endocrine receptors in some cases. ${ }^{8}$ Infertility in men and women, early puberty, and Polycystic Ovary syndrome can be given as examples of endocrine disorders in which BPA plays a pathogenic role. ${ }^{8}$ In addition, it is reported to be associated with low sperm count and motility, spontaneous abortion, and metabolic changes. ${ }^{13}$ When its effects on the reproduction system are examined it is seen that the main target is ovarian granulosa cells. The disruption of these cells by BPA can play an important role in fertility. ${ }^{12}$ Based on its effect on the androgen receptor, BPA is a known antagonist. ${ }^{15}$

The chemical structures of BPA and thyroid hormone have similarities. BPA has a property of binding to thyroid receptors competitively with thyroid hormone. It is seen to disrupt gene expression by thyroid receptors in vivo and in vitro. ${ }^{14}$

In addition to the mentioned effects, it is observed that BPA activates PXR from nuclear receptors and induces CYP3A4, environmental exposure to BPA can change 25-hydroxy vitamin $D$ level in circulation in adults, and there is a negative correlation between BPA and $25(\mathrm{OH}) \mathrm{D}$.

In other research, it was shown that BPA induces DNA damage in ER-positive MCF-7 cells and its genotoxicity is ER-dependent. It is observed that it induces micronucleus frequencies and chromosomal aberrations in rat bone marrow and causes DNA damage in lymphocytes. In a different study it was suggested that oxidative stress occurs by an increase in 8-hydroxyguanosine plasma levels and in LPO, and reduced glutathione activity in the liver. ${ }^{2}$

There are controversial results regarding the genotoxicity of BPA. Even though it is found to be negative according to basic genotoxicity tests, research shows that it induces chromosomal aberrations and morphological changes in Syrian hamster embryo (SHE) cells, achromatic lesions and c-mitotic effects in mice bone marrow, its metabolites bind to DNA in SHE cells and rodent liver, and it causes DNA damage in ER-positive MCF-7. ${ }^{2}$ Another study revealed that BPA causes ER-dependent DNA damage by inducing strand breaks in ER-positive MCF-7 cells. ${ }^{4}$ Vahdati Hassani et al. ${ }^{7}$ showed that protein and phosphoprotein levels involved in biological processes related to fatty liver, hepatotoxicity, and carcinoma are affected by BPA exposure. It is also found that BPA induces oxidative stress, an increase in malondialdehyde, and a decrease in glutathione (GSH). ${ }^{?}$ 
In 2008 concerns about the effects of current BPA exposure in fetuses, adults, and children on brain, behavior, and reproduction were declared in the report by the National Toxicology Program and in 2010 the FDA reported that they shared the same concerns.

BPA is banned in Japan, Canada, and most of US. In 2011 the EU forbade the production, marketing, and import of baby bottles containing BPA. ${ }^{2}$ In Turkey baby bottles and other food containers with BPA were collected by the Ministry of Agriculture in 2011.

\section{Bisphenol S}

BPS is an important analogue of BPA in industrial applications and an increasingly used alternative. ${ }^{6}$ The chemical nomenclature of BPS is bis (4-hydroxyphenyl) sulfone and it has a molecular weight of $250.27 \mathrm{~g} / \mathrm{mol}$.,16 BPS is a heat-resistant structural analogue of BPA. ${ }^{16}$ It has high thermal stability and is resistant to sunlight. 16,17

BPS is mostly used in several consumer products as a replacement for BPA. As the most commonly used alternative to BPA, BPS is commonly used in the production of thermal paper and plastics. 3.17

BPS is used as an improver in thermal paper and a stabilizer in canned soft drinks and canned food. ${ }^{6,16}$ In addition, it is used as an electroplating solvent, a fastening agent in cleaning products, and a constituent of epoxy resins in various industrial applications. ${ }^{5}$ As a commonly used analogue of BPA in production, the presence of BPS in nature and food is demonstrated in numerous studies. ${ }^{4}$ It was shown by the National Health and Nutrition Examination Survey that significant concentrations of BPS were detected in canned food, especially in canned vegetables and mushrooms. ${ }^{4}$ In addition, literature findings have shown that significant exposure occurs through dust. ${ }^{4}$ Moreover, the presence of BPS is detected in mud, water, tap water, and sewage..$^{5,6,11}$ In a previous study, BPS was detected in dust samples from various microenvironments and many products produced from thermal paper." BPS was detected in human tissues as well. ${ }^{6}$ BPS was found in human urine in concentrations and frequencies comparable to those of BPA. ${ }^{5}$ Especially after its detection in human urine, concerns about its safety were expressed. ${ }^{16}$

In addition to the types of exposure mentioned above, BPS was detected in many daily products. These products include personal care products, paper products, and food, with examples such as hair products, toothpaste, currency, mailing envelopes, dairy products, canned food, and cereals. ${ }^{5}$

Skledar et al. ${ }^{17}$ showed that glucuronidation is the main pathway in the metabolism and detoxification of BPS and UGT1A9 plays an important role in this process. ${ }^{17}$

Cumulative evidence suggests that BPS is toxic to organisms because its chemical structure is similar to that of BPA. Recently it was reported that, similar to BPA, BPS promotes estrogenic activity, proarrhythmic effects, and hypothalamic neurogenesis in vitro in cell cultures and in animals in vivo. When the estrogenic effects of BPA and BPS were compared in a study it was shown that the genomic estrogenic activity of 40 $\mu \mathrm{M}$ BPS is 15 times lower than that of BPA. It has toxic effects in the rat's endocrine system, adult zebra fish, breast cancer cells, and ovariectomized mice. ${ }^{6}$

BPS is stated to have toxic effects on the endocrine system similar to BPA in the literature. ${ }^{4}$ In other research it was reported that isopropylation of the 4-hydroxy group decreases BPS's estrogenic activity. ${ }^{17}$ BPS is also defined as a weak antiandrogenic compound. ${ }^{16}$

BPS exposure in zebra fish larvae suggests that oxidative stress parameters and interference of immune response is induced. ${ }^{6}$ In other research it was demonstrated that BPS inhibits pepsin activity, increases reactive oxygen species (ROS) levels in rats, induces lipid peroxidation (LPO), and decreases antioxidant enzyme activity.11

Furthermore, a recent study suggested a link between BPS exposure and obesity and steatosis. It was shown in an in vivo study that BPS may alter brain functions in mammals. ${ }^{17}$

In addition to the effects mentioned above when its genotoxic potential is examined, a study showed results on BPS exposure and genotoxicity including double strand breaks; however, it is seen that BPS has weaker genotoxic potential compared to BPA., In a study in HepG2 cells it was seen that BPA and BPS cause a significant increase in DNA damage. ${ }^{2}$ Moreover, BPS had effects on hepatic cells, bound to serum albumins, and caused DNA damage. ${ }^{5}$

When the association between BPS and thyroid hormone receptors is examined, it is seen that, similarly to BPA, it binds to thyroid hormone receptors. BPS can bind to both $\mathrm{TR} \alpha$ and $\operatorname{TR} \beta$ but its affinity to TR $\beta$ is higher..$^{14}$ In other research, in zebra fish embryos exposed to BPS at concentrations of 10 and 100 $\mu \mathrm{g} / \mathrm{L}$ for 75 days, triiodothyronine and thyroxine plasma levels were decreased. ${ }^{16}$

BPS exposure caused acute toxicity in Daphnia magna, induced uterine growth in rats, and in zebra fish it decreased the weight of gonads, altered plasma estrogen and testosterone, and caused reproductive disorders; it also increased the female ratio over males, decreased the body length, and caused changes in testosterone, estradiol, and vitellogenin concentrations and reproductive disorders. ${ }^{5}$ In nongenomic signal research BPS has a similar potency to BPA. From femtomolar to picomolar concentrations, BPS induced Era modulated pathways and activities such as membrane MAPK signaling, cell proliferation, and caspase 8 activation. These fast, nongenomic pathways have an important role in optimal cell function, and modulation of proliferation and apoptosis, beside activities such as pancreatic cell function and estrogen-modulated brain function. ${ }^{5}$

\section{Bisphenol F}

As an important and increasingly used analogue of BPA, the chemical nomenclature of BPF is 1,1-bis (4-hydroxyphenyl) methane and its molecular weight is $200.23 \mathrm{~g} / \mathrm{mol} .3,4,6 \mathrm{BPF}$ is used in the production of polycarbonate resin. ${ }^{2}$ In addition, BPF is used especially in systems that require increasing thickness and durability such as epoxy resins and coatings. ${ }^{6}$ 
Storage and pipe coatings, industrial floors, structural adhesives, bridge and road deck toppings, electrical varnishes, grouts, and coatings are examples of these systems. In addition, for different consumer products such as water pipes, plastics, food packaging, dental sealants, lacquers, adhesives, varnishes, and liners BPF epoxy resins are used. ${ }^{5}$

Even though it is more biodegradable under aerobic and anaerobic conditions compared to BPA, BPF has become an ubiquitous environmental contaminant. ${ }^{2,4}$ BPF has been detected in nature and food. ${ }^{4}$ The presence of BPF is reported in mud, tap water, indoor dust, water, sewage, and human tissues. ${ }^{6,11}$ In a recent study it was found in dust samples from various microenvironments and many products from thermal paper.11

A recent study showed that this compound accumulates in human urine. ${ }^{4}$ BPF is also detected in personal care products such as lotions and toothpaste, paper products such as tickets and envelopes, and foods such as canned food and cereals. ${ }^{5}$ Active BPF is distributed in many tissues including the placenta, uterus, fetus, and amniotic fluid. The primary elimination form of BPF is seen to be sulfate conjugate. ${ }^{5}$

So far evidence has suggested that, just like BPS, because of its similar chemical structure, BPF is toxic to organisms as BPA is. In studies BPF is reported to cause mild to moderate acute toxicity and weak estrogenic activity. ${ }^{6}$ In in vivo studies it is demonstrated to be estrogenic, androgenic, and thyroidogenic, while in vitro studies show that it is estrogenic, androgenic, and has other physiological/biochemical effects. There are studies showing that BPF exposure induces uterine growth in rats, which points to estrogenic activity. ${ }^{5}$ Studies show that BPF causes more potent estrogenicity compared to BPA. ${ }^{4}$

BPF exposure causes an increase in thyroid weight and changes in thyroid hormone concentrations. ${ }^{5}$ According to another study BPF can bind to both $\operatorname{TR} \alpha$ and $T R \beta$, but its affinity to $T R \beta$ is higher. $^{14}$

Furthermore, it causes changes in hematological parameters and enzyme expression. BPF has also shown other in vitro effects such as chromosomal aberrations, cytotoxic effects, DNA damage, and cellular dysfunction and decreased in vitro adiponectin production and release. ${ }^{5}$

BPF is reported to promote estrogenic activity comparable to BPA, proarrhythmic effects, and hypothalamic neurogenesis in vitro in cell lines and in vivo in animals. In addition, as a result of BPF exposure concentration-dependent increases in ROS content, nitric oxide and inducible nitric oxide synthase production, superoxide dismutase levels, T-AOC activity, LPO levels, and cytokine and chemokine expression in zebra fish larvae suggest that immune response and oxidative stress in fish are induced. ${ }^{6}$

BPF is reported to result in genotoxic damage that might interfere with DNA replication. In another study it was seen that BPF has weaker genotoxic potential compared to BPA. ${ }^{3}$ When the genotoxic effects of BPF are examined it is reported that BPF induces DNA damage but does not induce micronuclei frequencies in HepG2 cells. A recent study suggested that the genotoxic effect of BPF depends on the metabolic capacity of the cell. ${ }^{2}$

\section{Bisphenol AF}

The chemical nomenclature of BPAF is 2,2-bis (4-hidroxyphenyl) hexafluoropropane and its molecular weight is $336.23 \mathrm{~g} /$ mol.,4 It is used in the production of polycarbonate resin, is a component of certain plasters, and is used as a rubber bridging material. $^{2}$

BPAF is detected in the environment, tap water, bottled water, and canned food. ${ }^{4,11}$ In a recent study it was shown that it accumulates in human urine. ${ }^{4}$

When the effects of BPAF are examined, it is seen that BPAF causes more potent toxicity in cells including blood cells. In addition, in the literature it is demonstrated that BPAF binds more strongly to estrogen receptors and has more effects on gene expression compared to BPA. It is also demonstrated that BPAF presents genotoxic and neurotoxic potential. ${ }^{4}$

In their study Mokra et al. ${ }^{4}$ stated that BPA and BPAF have the highest genotoxic potential in incubated cells and they previously reported that BPA and BPAF induced the formation of ROS in peripheral mononuclear blood cells more potently and only BPAF caused a significant increase in $\mathrm{OH}$ levels in these cells. ${ }^{4}$ In other studies it was demonstrated that BPAF in high concentrations causes more potent DNA damage in MCF-7 cells compared to BPA. It is also reported to form micronuclei in V79 cells and induce aneuploidy in SHE cells. ${ }^{2,4}$ While causing metaphase arrest in V79 cells, it also causes morphological changes in SHE cells along with aneuploidy. ${ }^{2}$

In mammalian cells BPAF did not induce chromosomal aberration or gene mutation. Since toxicity data are insufficient and it has a similar structure to BPA, BPAF has been nominated for toxicological characterization by the US NIEHS. ${ }^{2}$

\section{Bisphenol Z}

The chemical nomenclature of BPZ is 1,1-bis (4-hydroxyphenyl) cyclohexane. BP compounds including BPZ have been found in different environmental and human samples. It is reported in different studies that concentrations of BPs in municipal waste water influents and effluents, sewage sludge, water, and sediments are elevated..$^{18}$

BPZ may be used in the synthesis of an anesthetic compound. ${ }^{19}$ Another area of use of BPZ is to cure highly heat resistant plastic materials and in electrical insulation. Several analogues of BPA, including BPF, BPS, and BPZ, are used in personal care products, food packaging materials, and paper products. ${ }^{20}$

Schmidt et al..$^{19}$ showed that BPZ was biotransformed in highest level of mobility (HLM) in a manner similar to the case of BPAF. According to their research based on the peak areas, hydroxylated BPZ was the main in vitro metabolite in HLM in the presence of nicotinamide adenine dinucleotide phosphate and $\mathrm{GSH}^{19}$

In their study, Lee et al. ${ }^{21}$ reported that BPZ exposure caused a decrease with varying changes in T3 and T4 levels. Kovačič et al..$^{18}$ stated that UV exposure is an effective way of removing 
BPF, BPS, and BPZ from water, showing the fastest degradation rate in the case of the photo-Fenton reaction. ${ }^{18}$

\section{OTHER BISPHENOLS}

The chemical nomenclature of BPC is 2,2-bis (4-hydroxy3-methylphenyl) propane, of BPM is 4,4'-(1,3-phenylenedii sopropilidene) BP, of BPAP is 4,4'-(1-phenylethylidene) BP, of BPP is 4,4'-(1,4-phenylenedii sopropilidene) bisphenol, and of bisphenol 1 is [sulfonylbis(4,1-phenylene)] bis (oxy) dimethanol. ${ }^{2,3}$ The molecular weight of BPAP is $290.36 \mathrm{~g} / \mathrm{mol}$, of BPC is $256.34 \mathrm{~g} / \mathrm{mol}$, of BPM is $346.46 \mathrm{~g} / \mathrm{mol}$, and of BPP is $346.46 \mathrm{~g} / \mathrm{mol}^{3}$

According to the study by Lee et al. ${ }^{3}$ some BPs including BPAP, BPM, and BPP showed greater genotoxic potential compared to BPA. BPP is reported to have the greatest genotoxic potency and is suggested to have an association with double strand breaks. $^{3}$

BP-1 is reported to be a component of polymer bottles. Polybutylene terephthalate modified by BP-1 is seen to improve glass transmission temperature and thermal stability. ${ }^{2}$

In their research Fic et al. ${ }^{2}$ demonstrated that BPA, BPAF, BPF, BPS, BPZ, BP-1, BP-2, DMBPA, and DMBPS are not mutagenic in the Ames test; however, DMBPA, BP-2, BPZ, and BPAF have toxic effects on Salmonella typhimurium. ${ }^{2}$

\section{Risk Assessment}

The current lowest-observable-adverse-effect level of BPA is determined as $50 \mathrm{mg} / \mathrm{kg}$ bodyweight per day by the US EPA. ${ }^{22}$ In hazard assessment protocol by the EFSA it is indicated that the current temporary tolerable daily intake (t-TDI) for BPA is $4 \mu \mathrm{g} /$ kg bw per day. ${ }^{23}$ Mikołajewska et al. ${ }^{24}$ reported that dietary BPA exposure in children is 1.088-4.492 $\mu \mathrm{g} /$ day, exposure to BPA in 3-month-old infants fed from polycarbonate bottles is 4-11 $\mu \mathrm{g} / \mathrm{kg}$ b.w./day, dietary exposure (canned food and beverages) in adults is $1.56-10.453 \mu \mathrm{g} /$ day, daily exposure to BPA through inhalation is $0.008-0.014 \mu \mathrm{g} /$ person/day, exposure to BPA from thermal paper is $71 \mu \mathrm{g} /$ day (exposure by $10 \mathrm{~h} /$ day), and exposure from paper currency is $0.0001-1.41 \mathrm{ng} / \mathrm{day} .{ }^{24}$ These data suggest that both children and adults may be exposed to BPA higher than the t-TDI mainly by dietary exposure and might result in toxic health outcomes. Although a t-TDI was not found for BP analogues, Wu et al. ${ }^{25}$ reported the following values for BP analogues in foodstuffs: BPS $<0.01 \mathrm{ng} / \mathrm{g}$, BPA $0.125 \mathrm{ng} / \mathrm{g}$, $B P F<0.05 \mathrm{ng} / \mathrm{g}, \mathrm{BPP}<0.025 \mathrm{ng} / \mathrm{g}$, and BPAF $<0.01 \mathrm{ng} / \mathrm{g}$ in the US between 2008 and 2012, which shows the other analogues to be lower than BPA. ${ }^{25}$

\section{CONCLUSION}

BPA is a widely produced and commonly used chemical. Due to its endocrine disrupting nature, it is associated with many diseases and disorders such as diabetes, breast cancer, obesity, cardiovascular diseases, renal diseases, chronic respiratory diseases, behavior disorders, thyroid hormone function disorders, tooth development disorders, and reproductive disorders. The respiratory system, central nervous system, cardiovascular system, immune system, and renal system are shown to be affected by BPA. It is also suggested that BPA has genotoxic and mutagenic potentials. Due to its toxic health effects, the use of alternative BPs has increased and BPA has been replaced by its chemical analogues such as BPS, BPF, BPAF, and BPZ. However, these replacing analogues are also BPs and it is suggested that they may pose similar or higher health risks for living organisms. In research BPS is reported to promote estrogenic activity, antiandrogenic activity, proarrhythmic effects, and hypothalamic neurogenesis in cell lines and to possess a potential of endocrine disruption similar to BPA. BPF is demonstrated to be estrogenic, androgenic, and thyroidogenic. BPAF is reported to cause more potent toxicity in cells, binding more strongly to estrogen receptors, and have more effect on gene expression compared to BPA, in addition to its neurotoxic and genotoxic potential. BPZ and other BPs also have structures similar to BPA and may show similar toxic effects. Therefore, it is important to examine the toxicological profile of these compounds and focus on risk assessment of BPA analogues to estimate the relationship between exposure and toxic outcomes. Further studies especially in humans are needed to shed light on the risk from BPA analogues.

Conflicts of interest: No conflict of interest was declared by the authors. The authors alone are responsible for the content and writing of this article.

\section{REFERENCES}

1. Ayazgök $B$, Tüylü Küçükkılınç T. Düşük Doz Bisfenol A'nın Büyük Etkileri. FABAD J Pharm Sci. 2017;42:139-150.

2. Fic A, Žegura B, Sollner Dolenc M, Filipič M, Peterlin Mašič L. Mutagenicity and DNA damage of bisphenol A and its structural analogues in HepG2 cells. Arh Hig Rada Toksikol. 2013;64:189-200.

3. Lee S, Liu X, Takeda S, Choi K. Genotoxic potentials and related mechanisms of bisphenol $A$ and other bisphenol compounds: a comparison study employing chicken DT40 cells. Chemosphere. 2013;93:434-440.

4. Mokra K, Kuźmińska-Surowaniec A, Woźniak K, Michałowicz J. Evaluation of DNA-damaging potential of bisphenol $A$ and its selected analogs in human peripheral blood mononuclear cells (in vitro study). Food Chem Toxicol. 2017;100:62-69.

5. Rochester JR, Bolden AL. Bisphenol S and F: A Systematic Review and Comparison of the Hormonal Activity of Bisphenol A Substitutes. Environ Health Perspect. 2015;123:643-650.

6. Qiu W, Shao H, Lei P, Zheng C, Qiu C, Yang M, Zheng Y. Immunotoxicity of bisphenol $\mathrm{S}$ and $\mathrm{F}$ are similar to that of bisphenol A during zebrafish early development. Chemosphere. 2018;194:1-8.

7. Vahdati Hassani F, Abnous K, Mehri S, Jafarian A, Birner-Gruenberger $\mathrm{R}$, Robati RY, Hosseinzadeh H. Proteomics and phosphoproteomics analysis of liver in male rats exposed to bisphenol A: Mechanism of hepatotoxicity and biomarker discovery. Food Chem Toxicol. 2018;112:26-38.

8. Kazemi S, Mousavi Kani SN, Rezazadeh L, Pouramir M, GhasemiKasman M, Moghadamnia AA. Low dose administration of Bisphenol A induces liver toxicity in adult rats. Biochem Biophys Res Commun. 2017;494:107-112. 
9. Eladak S, Grisin T, Moison D, Justine Guerquin M, N'Tumba-Byn T, Pozzi-Gaudin S, Benachi A, Livera G, Rouiller-Fabre V, Habert R. A new chapter in the bisphenol A story: bisphenol $S$ and bisphenol $F$ are not safe alternatives to this compound. Fertil Steril. 2015;103:11-21.

10. Er B, Sarımehmetoğlu B. Gıdalarda bisfenol A varlığının değerlendirilmesi. Vet Hekim Der Derg. 2011;82:69-74.

11. Maćczak A, Cyrkler M, Bukowska B, Michałowicz J. Bisphenol A, bisphenol $\mathrm{S}$, bisphenol $\mathrm{F}$ and bisphenol AF induce different oxidative stress and damage in human red blood cells (in vitro study). Toxicol In Vitro. 2017;41:143-149.

12. Molina AM, Abril N, Morales-Prieto N, Monterde JG, Lora AJ, Ayala N, Moyano R. Evaluation of toxicological endpoints in female zebrafish after bisphenol A exposure. Food Chem Toxicol. 2018;112:19-25.

13. Lee DW, Oh WY, Yi SH, Ku B, Lee MY, Cho YH, Yang M. Estimation of bisphenol A-Human toxicity by $3 \mathrm{D}$ cell culture arrays, high throughput alternatives to animal tests. Toxicol Lett. 2016;259:87-94.

14. Zhang YF, Ren XM, Li YY, Yao XF, Li CH, Qin ZF, Guo LH. Bisphenol A alternatives bisphenol $S$ and bisphenol $F$ interfere with thyroid hormone signaling pathway in vitro and in vivo. Environ Pollut. 2018;237:10721079.

15. Perera L, Li Y, Coons LA, Rene $H$, van Beuningen R, Goodwin B, Auerbach SS, Teng CT. Binding of bisphenol A, bisphenol AF, and bisphenol $S$ on the androgen receptor: Coregulator recruitment and stimulation of potential interaction sites. Toxicol In Vitro. 2017;44:287302.

16. Zenata O, Dvorak Z, Vrzal R. Profiling of bisphenol $S$ towards nuclear receptors activities in human reporter cell lines. Toxicol Lett. 2017;281:10-19.

17. Skledar DG, Schmidt J, Fic A, Klopčič I, Trontelj J, Dolenc MS, Finel M, Mašič LP. Influence of metabolism on endocrine activities of bisphenol S. Chemosphere. 2016;157:152-159.
18. Kovačič A, Gys C, Kosjek T, Covaci A, Heath E. Photochemical degradation of BPF, BPS and BPZ in aqueous solution: Identification of transformation products and degradation kinetics. Sci Total Environ. 2019;664:595-604.

19. Schmidt J, Kotnik P, Trontelj J, Knez Ž, Mašič LP. Bioactivation of bisphenol $A$ and its analogs (BPF, BPAF, BPZ and DMBPA) in human liver microsomes. Toxicol In Vitro. 2013;27:1267-1276.

20. Lee S, Kim C, Shin H, Kho Y, Choi K. Comparison of thyroid hormone disruption potentials by bisphenols $A, S, F$, and $Z$ in embryo-larval zebrafish. Chemosphere. 2019;221:115-123.

21. Lee J, Kim S, Choi K, Ji K. Effects of bisphenol analogs on thyroid endocrine system and possible interaction with $17 \beta$-estradiol using GH3 cells. Toxicol In Vitro. 2018;53:107-113.

22. Mileva G, Baker SL, Konkle AT, Bielajew C. Bisphenol-A: epigenetic reprogramming and effects on reproduction and behavior. Int J Environ Res Public Health. 2014;11:7537-7561.

23. European Food Safety Authority (EFSA), Gundert-Remy U, Bodin J, Bosetti C, FitzGerald R, Hanberg A, Hass U, Hooijmans C, Rooney AA, Rousselle C, van Loveren H, Wölfle D, Barizzone F, Croera C, Putzu C, Castoldi AF. Bisphenol A (BPA) hazard assessment protocol. 2017;14:1354E.

24. Mikołajewska K, Stragierowicz J, Gromadzińska J. Bisphenol A Application, sources of exposure and potential risks in infants, children and pregnant women. Int J Occup Med Environ Health. 2015;28:209241.

25. Wu LH, Zhang XM, Wang F, Gao CJ, Chen D, Palumbo JR, Guo Y, Zeng EY. Occurrence of bisphenol $S$ in the environment and implications for human exposure: A short review. Sci Total Environ. 2018;615:87-98. 